\title{
MIĘDZY REALIZMEM OBSERWACJI A WIZJĄ. PROCES TWÓRCZY I WARTOŚĆ JEGO REZULTATU NA PRZYKŁADZIE PIERWSZEJ CZĘŚCI NIE-BOSKIEJ KOMEDII ZYGMUNTA KRASIŃSKIEGO
}

Krasiński wizjoner, Krasiński myśliciel historiozoficzny - czy Krasiński myśliciel polityczny, społeczny - to bez watpienia pierwszorzędny problem badawczy. Ale można też postawić pytanie: na ile autor Irydiona spełniłby te wszystkie role, gdyby sam z siebie, nawet narzekając na brak ,anielskiej miary” poecie niezbędnej, nie wpisał się w projekt i poczet największych - jednak - artystów polskiego romantyzmu? Na ile jego refleksja mogłaby wybrzmieć z takim rezonansem, gdyby artykulacja myśli nie przekroczyła tej granicy, za którą już nie godzi się mówić wyłącznie o wyizolowanej strużce dyskursu, myśli wyabstrahowanej, ponieważ stanowią one jedno z kształtem swoistym, metaforyczną i obrazową nadorganizacją, decydującymi o statusie dzieła artystycznego? Przyznać trzeba od razu, o tym uczy historia naukowej recepcji pisarstwa Krasińskiego, że być może - najbardziej z romantyków - jest on predestynowany do takiego odbioru, może nawet bardziej niż Norwid - tyle wiemy z biografii autora Przedświtu o jego nadzwyczajnie intensywnym spalaniu się na drodze pracy umysłu, o wytężonej aktywności myśli, towarzyszącej mu od wczesnych lat chłopięcych; w tak dużym stopniu o specjalnym nacechowaniu jego utworów decyduje porządek zracjonalizowanej, logicznej myśli. Nawet tam, gdzie skłonnibyśmy byli dostrzegać wizyjność, profetyzm 
i aktualizację najbardziej ożywionej romantycznej amorficzności, zobaczyć można namysł, kalkulację i chłodny, racjonalny porządek. Tak pisze jeden z komentatorów twórczości Krasińskiego:

Czy naprawdę Nie-Boska to siostra rodzona Dziadów i Kordiana? Że pokrewna im - toć oczywiste. Ale równie chyba oczywiste, że nosi w sobie skłonności tamtym utworom obce. Ani śladu w niej przecie kompozycyjnego wzburzenia i wybuchowej gwałtowności, wyzwalających się w nieładzie, w dysproporcjach, w ogólnym zamąceniu harmonijnej architektoniki utworu. Wręcz przeciwnie: właśnie ład i klarowność - niemal klasycystyczne - stają się w Nie-Boskiej znamieniem intelektualizmu przenikającego wyraźnie cały jej organizm. Spokój, opanowanie, surowy rygoryzm proporcyj, nawiązań i analogij kompozycyjnych, nienaruszona, wyraźnie zarysowana symetria całości - sprawiają, iż zawichrzenia konstrukcji romantycznych zanikają tu niemal całkowicie (podkr. B.K.-Ch) ${ }^{1}$.

Bezsporny jest jednak fakt, że ta „linia intelektualna” pozostaje w związku z innymi, konstytutywnymi dla dzieła sztuki wymiarami, cechując indywidualny i niepowtarzalny charakter całego dzieła Krasińskiego. Specyfika artyzmu tego dzieła, wyznaczana przez charakterystyczne dla poety postawy twórcze, wydaje się rozpoznawalna z dużego nawet dystansu. Pozostaje jednak pytanie, czy to co utrwalone przez lektury, w rzeczywistości nieco domniemane, zyskuje swoje potwierdzenie w uważniejszych obserwacjach. Każdy niemal czytelnik Krasińskiego, doświadczając uroku i siły jego profetycznych prognoz, zdaje sobie jednocześnie sprawę z tego, że te wizje mają swoje korzenie, których obecność ma charakter pozaintelektualny lub nie przede wszystkim intelektualny; że żywioł doświadczenia i obserwacji odgrywa tu ważną rolę, chociaż to ostatnie rozpoznanie zdaje się rzadziej wynikać z samych tekstów czy modelowanych przez tradycję ponawianych lektur poety.

Proces twórczy, który pozostaje przedmiotem mojej uwagi - oczywiście w ustawicznym połączeniu z jego rezultatem, tzn. artystycznym

1 Czesław Zgorzelski, Nad Nie-Boskq komediq, w: tenże, Od Oświecenia ku Romantyzmowi i współczesności, Kraków 1978, s. 267. 
kształtem poezji romantyka - rozumiem nie psychologicznie, a - jak to nazywa Janusz Sławiński - bardziej operacyjnie ${ }^{2}$ (próba odtworzenia fragmentu jednego ciagu działań, w „wyniku których utwór formował się z określonego materiału”), jeszcze ściślej, będzie profilowany przez fenomenologiczne (Ingarden) widzenie dzieła, zatem każde rozpoznanie oparte zostanie na tym, co dostępne i możliwe do zobaczenia (odczytania) w samym utworze.

Dla wyraźniejszego zobrazowania problemu posłużę się kontekstem dość odległym od twórczości Krasińskiego, oczywiście zupełnie nie dla celów intertekstualnych, genetycznych, „wpływologicznych” itp., chodzi mi jedynie o wzmocnienie i uwypuklenie obserwacji.

Powszechnie znany jest z zapisów z epoki obraz Stanisława Wyspiańskiego, który z nieporuszoną uwagą chłonął całonocne, barwne wesele Lucjana Rydla i Jadwigi Mikołajczykówny. Wbrew czy w łączności z intencjami ówczesnych kronikarzy utrwaliła się legenda dramatopisarza, który odsłonił wówczas akt niezwykłej energii twórczej, kumulującej właśnie w postawie obserwatora, pozornie biernej, podporządkowanej do granic twórczych możliwości światu widzianemu, który to świat właśnie dyktował warunki konstrukcji i rozrostu dzieła. Zatem realizm i obserwacja stanęły u początku m.in. i takich scen:

\section{Panna Młoda}

Cięgiem ino rad byś godać, jakie to kochanie będzie.

\section{Pan Młody}

A ty wolisz całowanie -

będziesz kochać, a powiedzże - ?

\section{Panna Młoda}

Przeciem ci już wygadała.

Przecież ci mnie nikt nie wydrze.

\section{Pan Młody}

2 Proces twórczy, hasło w: Słownik terminów literackich, red. J. Sławiński, Wrocław 1998. Zob. również: Stanisław Jaworski, „Piszę więc jestem”. O procesie twórczym w literaturze, Łódź 1993. 
Serce do kochania radsze.

Toś już moja! Radość, szczęście!

Nie myślałem, że tak wiele 3 .

- po kilku, w tym duchu prowadzonych wypowiedziach nowożeńców, następuje zamknięcie sceny, w której uczestniczy tylko tych dwoje:

\section{Pan Młody}

Teraz ci mnie nic nie zwiedzie.

Takem pragnął, zboża, słońca...

\section{Panna Młoda}

Mos wesele! - Pódź do tońca!

A teraz spójrzmy na jedną, również zamkniętą scenę z Nie-Boskiej:

„Komnata petna osób - bal-muzyka - świece - kwiaty. P a n na M to da walcuje i po kilku okręgach staje, przypadkiem napotyka męża w tlumie i głowe opiera na jego ramieniu.

\section{Pan Młody}

Jakżeś mi piękna w osłabieniu swoim - w nieładzie kwiaty i perły na włosach twoich - płoniesz ze wstydu i znużenia - o wiecznie, wiecznie będziesz pieśnią moją.

\section{Panna Młoda}

Będę wierną żoną tobie, jako matka mówiła, jako serce mówi. - Ale tyle ludzi jest tutaj - tak gorąco i huczno.

\section{Pan Młody}

Idź raz jeszcze w taniec, a ja tu stać będę i patrzeć na cię, jakem nieraz w myśli patrzał na sunących aniołów.

3 Wszystkie zacytowania Wesela pochodzą z: Stanisław Wyspiański, Wesele, oprac. J. Nowakowski, Wrocław 1981, s. 20-21. 


\section{Panna Młoda}

Pójdę, jeśli chcesz, ale już sił prawie nie mam.

\section{Pan Młody}

Proszę cię, moje kochanie ${ }^{4}$.

Kiedy już uwolnimy się - jako czytelnicy - od wrażenia oszałamiającego nieco skontrastowania obu fragmentów (czynniki decydujące o tym kontraście są chyba dość oczywiste) zastanawia, może - zdumiewa, bardzo mocne i jednoznaczne pole tożsamości całej przestrzeni znaczeń, uruchomionej przez dialogi obu dramatów. Wyznaczają je: rozmowa młodych małżonków o miłości, werbalne uwiarygodnianie uczucia (zapewnianie o jego dozgonności, napawanie się faktem współprzynależności, kontemplacja urody żony i jej obecności; na różne sposoby wyrażane intensywność i autentyzm tych uczuć, deklarowane i „dokonywane” posłuszeństwo w imię miłości - w obu scenach pójście do tańca zamyka passus); detalami przeżyciowymi malowany realizm sytuacji (ludzie, gorąco, huczno).

Krasiński, zapatrzony niemal tak, jak ponad pół wieku później Wyspiański, z ostrością postrzega stany wewnętrzne bohaterów, uwikłane, wydawałoby się, w największe społeczne stereotypy, i wykorzystuje je jako podstawowy materiał swojej dramatycznej konstrukcji.

Pisząc o miłości małżeńskiej w wielu fragmentach podporządkowuje stylizację biblijnej Pieśni nad Pieśniami (,Jakżeś mi piękna w osłabieniu swoim...”, „Powiedz mi, drogi, co masz, bo głos twój niezwyczajny i gorączką nabiegły ci jagody...") ${ }^{6}$. Duch tej biblijnej księgi unosi się nad całością części pierwszej trochę na zasadzie kontrapunktu w stosunku do wyzwań, jakie przynosi w jej obręb dziewica - kusicielka. Charakterystyczne, że nawiązania biblijne w Nie-Boskiej (przynajmniej na poziomie pierwszej części dramatu, ale chyba nie tylko) służą przede wszystkim wzmocnieniu realizmu. Irena Sławińska

\footnotetext{
4 Zygmunt Krasiński, Nie-Boska komedia, oprac. S. Treugutt, Warszawa 1978, s. 10-11.

5 Tamże, s. 10.

6 Tamże, s. 12.
} 
w swoim szkicu o rozmowach w III cz. Dziadów ${ }^{7}$ pisze, że u Mickiewicza frazy biblijne podporządkowane są nie prawu realizmu, a prawu uogólnienia; można ten sąd uzupełnić - Mickiewicz wykorzystuje tekst biblijny dla kolorytu patetycznego poszczególnych przedstawień, dla usakralnienia wydarzeń; u Krasińskiego funkcja Biblii jest niemal odwrotna; Biblia wyjaśnia i uzupełnia realia, wydobywa je; wprowadzana raczej na zasadzie podporządkowania prawu pojedynczej (nie obejmującej większe całości) metafory, informacji; nie - uogólnieniu, a często - jakby dopełnianiu obszaru faktów i informacji.

Dramat Męża nie zyskałby takiej siły realnego psychicznego i duchowego przeżycia, gdyby nie świadomość bohatera, u źródeł której stoi wiedza biblijna:

\section{Mąż}

Chodzi i załamuje ręce.

Boże, czyś Ty sam uświęcił związek dwóch ciał? czyś Ty sam wyrzekł, że nic ich rozerwać nie zdoła, choć dusze się odepchną od siebie, pójdą każda w swoją stronę i ciała gdyby dwa trupy zostawią przy sobie? ${ }^{8}$

Krasiński myśli Biblią. Ta wymowna i w pełni koherentna z całością części pierwszej obecność tekstu biblijnego - wlaśnie w planie realistycznym - stanowi ukrytą motywację czy estetyczne uzasadnienie (na zasadzie ukrytej symetrii) np. końcowego dla dramatu obrazu Chrystusa ukrzyżowanego, który pojawił się w planie wizyjnym dramatu. Warto też od razu zauważyć, że część pierwsza - mimo obecności dziewicy - ułudy - ma charakter bardziej zdominowany przez rzeczywistość doświadczaną uniwersalnie i realnie, podczas kiedy druga - z konieczności kompozycyjnej jakby bardziej skrótowa, jeśli wziąć pod uwagę ogrom problematyki - podporządkowana jest w większym stopniu prawu wizyjności.

Irena Sławińska, O rozmowach w III części „Dziadów”, Lublin 1957, s. 18-22.

8 Krasiński, Nie-Boska..., dz. cyt., s. 13. 
Wróćmy jeszcze do szczegółowych zagadnień związanych z częścią pierwszą Nie-Boskiej.

Dramat Męża i Żony zbudowany został na pogłębionym psychologicznie i oddającym realia studium małżeństwa. Tragedia rodziny daje się tu wyjaśnić podłożem oczywistego psychologicznie pragnienia oddania i poświęcenia Żony na rzecz miłości Męża. Dziewica - kusicielka - jej sprawcza moc - nie miałaby możliwości tak destruktywnego wpływu na sytuację, gdyby nie krańcowe, ale jednocześnie tak ludzkie i uzasadnione realiami uczucie Żony. Zresztą dylematy Męża i Dziewica-ułuda potraktowana symbolicznie ukrywa - jako element zewnętrznego jakby obrazu - sposób działania Męża, co w całości przekłada się na opis mechanizmów działającej pokusy. Krasiński - autor pierwszej części Nie-Boskiej jawi się tu - powtórzę - jako doskonały obserwator; obserwacja jest punktem wyjścia, impulsem, dla mających nastąpić później (w drugiej części) konstruktów bardziej wizyjnych.

Związek dwojga, mimo ostatecznej katastrofy, przedstawiony jest przez poetę z większą dozą jakiegoś „realizmu uniwersalnego”, aniżeli np. pary Mickiewicza, nie mówiąc już o Słowackim. Pod kategorię takiego realizmu, zagarniającego rzeczywistość duchową, dają się wpisać np. takie fragmenty:

\section{Żona}

Bogu dzięki, że już raz się odbędzie ten obrządek - że Orcio nasz zupełnie chrześcijanem się stanie - bo choć już ochrzczony z wody, zdawało mi się zawsze, że mu nie dostaje czegoś.

Idzie do kolebki.

Śpij, moje dziecię - czy już się tobie coś śni, że zrzuciłeś kołderkę - ot, tak - teraz leż tak. - Orcio mi dzisiaj niespokojny - mój maleńki - mój śliczny, śpij'.

Fragment przedstawia pospolite niemal, powtarzalne, społecznie i religijnie usankcjonowane myślenie o dziecku wobec sakramentu

\footnotetext{
9 Tamże, s. 15.
} 
chrztu. Krasiński nie jest tu romantykiem, a obserwatorem świata ludzi w konkretnych realiach geograficzno-historycznych.

Odnajdujemy też w pierwszej części Nie-Boskiej ślady znakomitej i nowoczesnej psychologii moralnej autodestrukcji (walka między poczuciem powinności wynikającej z przyjętego sakramentu, a pokusą życia dla sztuki):

\section{Mąż}

Słuchaj, Mario, może ty udajesz, skryłaś się gdzie, żeby mnie ukarać? Ozwij się, proszę cię, Mario - Marysiu!

Nie - nikt nie odpowiada. - Janie - Katarzyno! - Ten dom cały ogłuch oniemiał.

Tę, której przysiągłem na wierność i szczęście, sam strąciłem do rzędu potępionych już na tym świecie. - Wszystko, czegom się dotknął, zniszczyłem i siebie samego zniszczę w końcu. - Czyż na to piekło mnie wypuściło, bym trochę dłużej był jego żywym obrazem na ziemi? Na jakiejże poduszce ona dziś głowę położy? - Jakież dźwięki otoczą ją w nocy? ${ }^{10}$

Sceneria poszukiwania żony, konkretyzm i niezwyczajna jak na romantyzm codzienność przywołań, stają się naturalną ramą dla autentycznego wewnętrznego dramatu bohatera (wziąwszy w nawias językowe naleciałości epoki, można powiedzieć - jak w Sednie sprawy Greena).

$\mathrm{Na}$ rozmaitych poziomach i w różnych kontekstach pojawiają się ślady zmysłu obserwacyjnego autora; akcenty na wskroś realistyczne i poprzez mocne nacechowanie sensualne ten realizm aktualizujące, np.:

Parno - duszno - burza się gotuje - rychło tam ozwie się piorun, a tu pęknie serce moje? ${ }^{11}$

W tym fragmencie realistyczna aktualizacja przechodzi w metaforyczną, ale nie fantazyjną mowę o stanie swojego wnętrza. W duchu

\footnotetext{
10 Tamże, s. 23.

11 Tamże, s. 15.
} 
tego realizmu, przywołany już, ekspresywny fragment (z frazą: ,zniszczyłem i siebie samego zniszczę w końcu”) przechodzi w zimne, introspektywne właściwie, mimo dramatycznego przypisania „Głos skądsiś”: „Dramat układasz”12.

Każda niemal scena, będąca wielkim metaforycznym skrótem, nacechowana wizją przyszłości i dynamiką już nie realnego obrazu, wyrasta $z$ fragmentów przesyconych wnikliwą obserwacją świata i własnego (autorskiego) wnętrza.

Decyduje ona również o sile kontrastów między poszczególnymi całostkami, które - być może - stanowią o specyfice artyzmu Krasińskiego i sile ekspresji jego utworów.

Na przykład, cytowany na początku i zestawiony z Weselem Wyspiańskiego dla zobrazowania siły wymiaru realistycznego fragment dialogu Pana Młodego z Panną Młodą, umieszczony został w bezpośrednim sąsiedztwie (oddzielony tylko trzema gwiazdkami) krótkiego fragmentu z „D u c h e m Zły m pod postacią dziewicy lecącym”:

Niedawnom jeszcze biegała po ziemi

w taką samą porę - teraz gnają mnie czarty

i każą świętą udawać.

Leci nad ogrodem

Kwiaty odrywajcie się i lećcie do moich włosów.

\section{Leci nad cmentarzem}

Świeżość i wdzięki umarłych dziewic, rozlane

w powietrzu, płynące nad mogiłami

lećcie do jagód moich ${ }^{13}$.

Ten kontrast nie odzwierciedla zwykłego prawa kontrastu. Obrazuje, odzwierciedla - jak się wydaje - podstawową zasadę twórczą obowiązującą w twórczości Krasińskiego; głęboko zakorzeniony i wielo-

\footnotetext{
12 Tamże, s. 23.
}

13 Tamże, s. 11. 
poziomowy realizm (wymiar obserwacji faktograficznej, kolorytu miejsc; wymiar jednostkowego wnętrza - realizm psychiki, realizm ducha; wymiar związku dwojga), który projektuje, wyzwala, intensywną czynność intelektualną decydującą o powstaniu wizji i o jakości wizji. Jej miarą jest przestrzeń między obserwacją (tu rozumiem również własne doświadczenie), a siłą intelektualnego (wyrażę się metaforycznie) ,rzutu” w wyobrażaną przyszłość.

Zwróciłam uwagę wcześniej, że dająca się zauważyć już na początku Nie-Boskiej wyraźna eksplikacja realnego doświadczenia duchowo-biblijnego w planie nawet wyłącznie estetycznym - bo o to mi w tej chwili chodzi - decyduje o absolutnej adekwatności końcowej sceny z wizją Chrystusa; w żaden sposób nie daje się - w tym kontekście estetycznej analizy - ocalić sądu Przybosia, że ta puenta dramatu jest genialnym, ale kiczem. Przyboś uległ jakby własnemu wyłącznemu widzeniu ,ścieżki” fantastycznej, coś zachwiało jego percepcją tak, że nie był w stanie jednocześnie - tak jak to narzuca tekst Nie-Boskiej - percypować ścieżki realnej obserwacji i realnego doświadczania świata przez osobę autora, m.in. jak wspominałam, określonego (tego doświadczenia) lekturą Biblii. Taki realizm ,ja” mówiącego w poezji Krasińskiego jest bardzo widoczny, niekoniecznie, jak przywykliśmy do tej pory, jego przesłanki dają się wyczytać przede wszystkim z prac dotyczących biografii poety.

Jeśli proces twórczy pozostaje symetryczny w stosunku do aktu percepcji, przeżycia estetycznego, wówczas, uwzględniając jego schemat (tego przeżycia) zrewidowany i opisany przez Romana Ingardena, można zobaczyć emocję wstępną jako moment odpowiadający autorskiemu zanurzeniu w realnym świecie. To spostrzeżenie, samo w sobie dość oczywiste, prowadzi do mniej oczywistego rozpoznania, odsłaniającego specyfikę twórczości Krasińskiego, że faza kolejna - podmiotowej aktywności - odpowiada identyfikowalnej w dziele poety intelektualnej sile prowadzącej do zaistnienia wizji.

Przemienność bardziej jakby percepcyjno-kontemplatywnego momentu (odbiór świata) i fazy aktywnej (budowania wizji) odpo- 


\section{wiada uproszczonej do schematu przemienności przeżycia este- tycznego ${ }^{14}$.}

Można też, przyjmując tezę francuskiego estetyka Mikela Dufrenne`a, że struktura dzieła sztuki wykazuje podobieństwo do struktury osoby ludzkiej ${ }^{15}$ i łącząc „strefę realną” dzieła Krasińskiego z tym, co zachowała kontemplatywna pamięć (zatem - przeszłością) ze „strefą wizji”, próbą rozjaśnienia przyszłości i nastawieniem na przyszłość, wprowadzić jedną z kluczowych antropologicznych tez Bergsona:

Ciagły ruch do przodu, gromadzący całą przeszłość i tworzący przyszłość - taka właśnie jest zasadnicza natura osoby.

I jeszcze:

[...] dwoma zasadniczymi aspektami ludzkiej osobowości są: po pierwsze, Pamięć, obejmująca cały zakres nieświadomej przeszłości, w taki sposób, by w każdym momencie móc uświadomić sobie tę jej część, którą będzie można wykorzystać; oraz, po drugie, Wola, nieustannie napinająca się ku przyszłości.[...] Być człowiekiem jest samo w sobie napięciem ${ }^{16}$.

Twórczość Krasińskiego jest kolejnym romantycznym wariantem zagęszczonej egzemplifikacji tego, co w sposób bardzo podstawowy decyduje o byciu osobą.

14 Por. fazy przeżycia estetycznego wyodrębnione przez R. Ingardena, w: tenże, Przeżycie estetyczne, w: Wybór pism estetycznych, wprowadzenie, wybór i oprac. A. Tyszczyk, Kraków 2005 .

15 Eugenia Basara-Lipiec, Arcydzieło. Teoria i rzeczywistość, Warszawa 1997, s. 57.

16 Henri Bergson, Problem osobowości, tłum. P. Kostyło, posłowie, St. Borzym, Warszawa 2004, s. 204-205. 


\begin{abstract}
Bernadetta Kuczera-Chachulska, Between realism of observation and vision. Creative process and the value of its outcome. A case study of Zygumnt Krasiński's The Un-Divine Comedy.
\end{abstract}

The article touches upon the characteristics of Zygmunt Krasiński's creative process. The author analyses this issue in reference to the wellestablished in the history of literature argument of predominantly intellectual, historiosophical and visionary background to Krasiński's writing. Using the example of the first part of The Un-Divine Comedy, she brings forward an argument on the weight and relevance of realistic observation of reality in the writings of this romantic author.

Transl. Mateusz Falkowski 